Jurnal At-Tibyan: Jurnal Ilmu Alqur'an dan Tafsir

Volume 5 No. 2, Desember 2020 (h.240-258)

P ISSN 2442-594X | E ISSN 2579-5708

http://journal.iainlangsa.ac.id/index.php/tibyan

\title{
A SUFISM PSYCHOLOGICAL ANALYSIS OF ISMĀ'ÎL'S INTRAPERSONAL COMMUNICATION IN SURAH AL-ȘĀFFĀT [37]: 102
}

\author{
Mahbub Ghozali \\ Universitas Islam Negeri Sunan Kalijaga Yogyakarta, Indonesia \\ mahbub.ghozali@uin-suka.ac.id \\ \begin{tabular}{|l|l|l|}
\hline \multicolumn{2}{|c|}{ DOI 10.32505/jurnal at-tibyan.v5i2.1471 } \\
\hline Submitted: 08-03-2020 & Revised: 09-09-2020 & Accepted: 26-10-2020 \\
\hline
\end{tabular}
}

\begin{abstract}
Dialogue between Ismā'îl and Ibrāhîm in Q.S. al-Ṣaffāt [37]: 102, is not only focused on the polemic of the determination about child referred in the verse. Likewise, the discussion about this verse is not only abaout ideal model of education for children. Another discussion no less interesting is regarding the response of the Ismā'îl when listening to the slaughtering order from Ibrāhìm. Although there is no indication in the verse that reffer to communicative process in Ismā'îl to response that command. But in the context of communication, the reception of the message conveyed, allows him to respond the message. To provide a response, symbol processing is needed. So that it can provide an appropriate response. Therefore, to find this process, this study uses a text analysis method with a Sufi Psychological approach. By using these methods and approaches, this study concludes that intrapersonal communication in Ismā'îl involves self-entities consisting of al-rûh, al-'aql, and al-qalb. These three entities have their respective concepts of knowledge which clarify one another. In Ismā'îl, the concept of reason knowledge gained from his experiences gives confidence to the truth of the command. Likewise, the maturity of the soul makes it easy for the heart to gain intuitive knowledge that is affirmed by reason, giving rise to an acceptance response to the order.
\end{abstract}

Keywords: al-Ṣāffât [37]: 102, Sufism Psychology, Ismā'îl, Intrapersonal Communication. 


\begin{abstract}
Abstrak
Dialog antara Ismā'ìl dengan Ibrāhīm dalam Q.S. al-Ṣaffāt [37]: 102, tidak hanya terfokus pembahasannya dalam polemik penentuan anak yang dimaksud dalam ayat tersebut. Begitu juga, pembahasan dalam ayat tersebut tidak hanya terbatas pada model pendidikan ideal terhadap anak. Pembahasan yang juga tidak kalah menarik adalah berkenaan dengan respon Ismā'il ketika mendengarkan perintah penyembelihan dari Ibrāhīm. Meskipun tidak ada indikasi dalam ayat tersebut bahwa adanya proses komunikatif dalam diri Ismā'il dalam merespon perintah tesebut. Akan tetapi dalam konteks komunikasi, penerimaan pesan yang tersampaikan, memungkinkan dirinya untuk merespon pesan tersebut. Untuk memberikan tanggapan atas respon tersebut, dibutuhkan proses pengolahan simbol, sehingga dapat memberikan tanggapan yang sesuai. Oleh sebab itu, untuk menemukan proses tersebut, penelitian ini menggunakan metode analisis teks dengan pendekatan psikologi sufistik. Dengan menggunakan metode dan pendekatan tersebut, penelitian ini menyimpulkan bahwa komunikasi intrapersonal dalam diri Ismā'il melibatkan entitas-entitas diri yang terdiri dari al-rūh, al- 'aql, dan al-qalb. Ketiga entitas ini memiliki konsep pengetahuan masing-masing yang saling mengklarifikasi satu dengan yang lain. Dalam diri Ismā'ìl, konsep pengetahuan akal yang diperoleh dari pengalaman-pengalamannya memberikan keyakinan terhadap kebenaran perintah. Begitu juga, kematangan jiwa memberikan kemudahan bagi hati dalam memperoleh pengetahuan intuitif yang diafirmasi oleh akal, sehingga memunculkan respon penerimaan at as perintah tersebut.
\end{abstract}

Kata Kunci: al-Ṣäffăt [37]: 102, psikologi sufistik, Ismā'īl, Komunikasi Intrapersonal.

\title{
Pendahuluan
}

Surat al-Șāffāt ayat 102 menceritakan tentang dialog antara seorang bapak dan anak dalam kontek perintah untuk penyembelihan. Kisah dalam potongan ayat ini merupakan satu jalinan kisah dengan ayat sebelumnya. Ulama' tafsir tidak berselisih paham mengenai identifikasi bapak yang dimaksud dalam ayat ini. Secara mayoritas, Ulama' tafsir mengidentifikasi bapak yang dimaksud adalah Ibrahim. ${ }^{1}$ Sedangkan perbedaan mulai nampak ketika berkaitan dengan identifikasi anak yang dimaksud dalam ayat ini. Beberapa kalangan menyebutkan bahwa anak yang dimaksud dalam ayat tersebut adalah Ishāq, sedangkan sebagian yang lain menyebutnya Ismā'î̀, seperti yang dilakukan oleh Ibn Kathï.' Agar tidak terjerumus dalam perdebatan tersebut, maka penelitian ini mengambil pendapat berdasarkan mayoritas Ulama' tafsir yang

\footnotetext{
${ }^{1}$ Muhammad bin Jarīr Al-Tabarì, Jāmi’ Al-Bayān Fì Ta’wīl Al-Qur'an, vol. 4 (Bairut: Muassasah alRisālah, 2000), 314.

${ }^{2}$ Ismāil bin Umar bin Kathīr, Tafsìr Al-Qur'an Al-'Aẓim, vol. 7 (Beirut: Dār al-Tayyibah, 1999), 27.
} 
menyebutkan bahwa ayat tersebut berkaitan dengan komunikasi yang dilakukan Ibrāhīm dan Ismāil.

Beberapa pengkaji tentang tafsir ayat ini dapat di tipologikan menjadi tiga kecenderungan, yakni model pendidikan anak, penanaman karakter, dan metode komunikasi dalam wilayah pendidikan. Tipe penelitian pertama dilakukan oleh Zaimuddin $^{3}$, Rahmadianti Aulia ${ }^{4}$, dan Zainol Hasan ${ }^{5}$. Tipe kedua dilakukan oleh Miftahur Rahmah ${ }^{6}$, Alimul Muniro ${ }^{7}$, Budihardjo ${ }^{8}$, dan Saiful Falah ${ }^{9}$. Sedangkan tipe ketiga dilakukan oleh Zeni Murtafiani Mizani ${ }^{10}$, dan Siti Mahmudah ${ }^{11}$.

Akan tetapi hal yang paling urgent dalam penyebutan kisah ini pada dasarnya terletak pada penggambaran seorang hamba yang taat, yang mengikuti perintah yang diberikan Tuhan meskipun perintah tersebut secara manusiawi berat untuk dilakukan. Karena pada hakekatnya kisah dalam al-Qur'an salah satunya difungsikan untuk menjelaskan pondasi dakwah para Nabi tentang keta'atan kepada Allah. ${ }^{12}$ Perintah yang dalam kategori manusia biasa tergolong pada perintah yang sulit untuk dilakukan, namun dalam kisah tersebut, keduanya menjalankan perintah sesuai dengan kehendak yang diinginkan oleh Allah.

Komunikasi yang terdapat dalam ayat ini adalah pola komunikasi singkat. Ketika Ibrāhīm mengutarakan niatnya untuk menyembelih Ismāil yang didasarkan pada mimpi, Ismāil langsung menyetujui dan mempersilahkan Ibrāhīm untuk melaksanakan perintah tersebut. Menurut Carl I. Hovland yang dikutip Widjaya, komunikasi adalah suatu pesan yang dipindahkan sebagai rangsangan bagi orang lain yang dituju dalam

\footnotetext{
${ }^{3}$ Zaimudin Zaimudin, "Karakter Nabi Ibrahim AS Dalam Al-Qur'an," Al-Fanar: Jurnal Ilmu AlQur'an Dan Tafsir 1, no. 1 (August 30, 2018): 35-74, https://doi.org/10.33511/ALFANAR.V1N1.35-74.

${ }^{4}$ Rahmadianti Aulia, "Peran Ayah Dalam Pengasuhan: Tinjauan Kisah Nabi Ibrahim Dan Nabi Ismail Dalam Al-Qur'an," Al-Qalb : Jurnal Psikologi Islam, vol. 8, 2017, https://doi.org/10.15548/ ALQALB.V8I2.875.

${ }^{5}$ Zainol Hasan, "Nilai-Nilai Pendidikan Islam Pada Kisah Nabi Ibrahim," Nuansa: Jurnal Penelitian Ilmu Sosial Dan Keagamaan Islam 14, no. 2 (March 1, 2018): 423, https://doi.org/10.19105/ nuansa.v14i2.1642.

${ }^{6}$ Miftahur Rahmah, "Mendidik Anak Shaleh: Telaah Kisah Nabi Ibrahim A.S. Dan Ismail A.S.," Turast: Jurnal Penelitian Dan Pengabdian 7, no. 1 (July 30, 2019): 45-64, https://doi.org/10.15548/ turast.v7i1.763.

${ }^{7}$ Alimul Muniroh, "Implementasi Nilai-Nilai Pendidikan Islam Dalam Surah As-Saffat Ayat 102," Darajat: Jurnal Pendidikan Agama Islam 1, no. 1 (March 3, 2018): 1-15.

${ }^{8}$ Budihardjo Budihardjo, "Pendidikan Nabi Ibrahim Dan Anaknya Dalam Perspektif Al-Qur'an (Q.S. Al-Shafat [37]: 102 - 107)," Millah 9, no. 2 (February 15, 2010): 191-206, https://doi.org/ 10.20885/millah.vol9.iss2.art2.

9 Saiful Falah, "Pendidikan Karakter Berbasis Keluarga Pada Kisah Nabi Ibrahim Dan Ismail," Ta'dibuna: Jurnal Pendidikan Islam 9, no. 1 (April 30, 2020): 133, https://doi.org/10.32832/ tadibuna.v9i1.2976.

${ }^{10}$ Zeni Murtafiati Mizani, "Komunikasi Orang Tua Dan Anak Dalam Islam (Tinjauan Pedagogis Komunikasi Nabi Ibrahim Dengan Nabi Isma'il Dalam Al-Qur'an)," Ibriez : Jurnal Kependidikan Dasar Islam Berbasis Sains 2, no. 1 (June 20, 2017): 95-106, https://doi.org/10.21154/ibriez.v2i1.28.

${ }^{11}$ Siti Mahmudah, "Interaksi Pendidikan Islam Dalam Al Qur'an (Kisah Nabi Ibrahim Dan Nabi Ismail)" (Universitas Muhammadiyah Surakarta, 2010).

12 Mannā' Khāil Al-Qaț̣ān, Mabāhith Fì Ulüm Al-Qur'an (Riyāụ: Manshūrāt al-'Așr al-Ḥadith, 1973), 307.
} 
bentuk lambang-lambang, kata-kata untuk mengubah tingkah-laku orang lain. ${ }^{13}$ Rangsangan ini yang kemudian dipindahkan oleh Ibrāhīm, sehingga Ismāil memberikan respon. Respon yang diberikan Ismāil tidak terjadi secara spontan, akan tetapi respon tersebut dipengaruhi oleh pemahamannya tentang simbol-simbol yang ada dalam komunikasi Ibrāhìm yang disamapaikan, sehingga pemahaman atas simbol-simbol tersebut terlaksana sebagai bagian dari ketaatan beragama. Proses pemahaman dalam diri Ismāil terhadap simbol-simbol komunikasi tersebut terjadi secara personal, sehingga model semacam ini disebut dengan komunikasi intrapersonal.

Dalam kajian dan penelitian yang dilakukan sebelumnya, proses komunikasi dalam diri Ismāil (intrapersonal) tidak pernah disinggung sebelumnya. Proses ini justru menentukan pilihan Ismā'il atas perintah tersebut, sehingga ia dapat menerima perintah untuk penyembelihan. Bahkan, aspek komunikasi intrapersonal dapat menjelaskan dan membangun makna baru dalam penjelasan ayat tersebut. Pemaknaan al-sa'y (sanggup) yang diidentikkan dengan usia, justru dapat dikembangkan dengan pemaknaan lain yang lebih relevan. Atas dasar tersebut, penelitian ini bertujuan untuk menemukan relasi baru dalam dialog antara Ismā'ìl dan Ibrāhīm dalam aspek pembangunan aspek ketaatan dalam diri Ismā'ill. Proses ini juga akan memberikan pemaknaan baru atas term-term tertentu dalam ayat tersebut.

Untuk mencapai tujuan tersebut, penelitian ini berangkat dari asumsi bahwa ketaatan yang ditunjukkan oleh Ismā'il bukan bagian dari anugerah yang diberikan oleh Allah kepada manusia pilihannya. Akan tetapi merupakan sebuah sikap yang dibangun dalam proses yang panjang, sehingga ketika proses tersebut dianggap selesai, maka perintah untuk menguji ketakwaannya diturunkan. Argumentasi ini berangkat dari penggunaan kata al-sa'y (kesiapan) yang digunakan untuk membuka proses dialog tersebut. Dalam kajian psikologis, dorongan-dorongan dari dalam diri seseorang dilandasi oleh keinginan untuk memenuhi kebutuhan mendasarnya. ${ }^{14}$ Dalam konteks kisah ini, kebutuhan yang dimaksud adalah kebutuhan untuk mendekatkan diri kepada Tuhan yang merupakan pemenuhan atas potensi luhur yang dimiliki oleh Ismà'il. Kebutuhan dalam model ini disebut oleh Abraham Moslow sebagai kebutuhan metamotivasi. ${ }^{15}$

Oleh sebab itu, untuk menemukan proses tindakan yang dilakukan Ismā'il dalam ayat tersebut penelitian ini menggunakan metode kualitatif dengan teknik penelitian studi pustaka. Sebagai perangkat analisa data, penelitian ini juga menggunakan metode analisis teks dengan pendekatan psikologis sufistik. Metode ini dapat menganalisa motif dan dorongan dalam diri seseorang untuk melakukan suatu tindakan dengan dasar klasifikasi sufistik. Dalam penerapannya, analisa diakronik digunakan untuk mempertemukan analisa atas teks dengan unsur-unsur psikologi sufistik agar dapat

\footnotetext{
${ }^{13}$ H.A.W. Widjaya, Komunikasi Dan Hubungan Masyarakat (Jakarta: Bina Aksara, 1986), 26.

${ }^{14}$ Muzafer Sherif and Carolyn W. Sherif, An Outline of Social Psychology (New York: Harper \& Row, 1956), 181.

${ }^{15}$ Abraham H. Maslow, Motivation and Personality (New York: Harper \& Row, 1954), 149.
} 
menghasilkan kesimpulan yang simbang tanpa menghilangkan nuansa tafsir dalam penelitian ini.

\section{Komunikasi Ibrāhīm dan Ismāil dalam Kajian Tafsir}

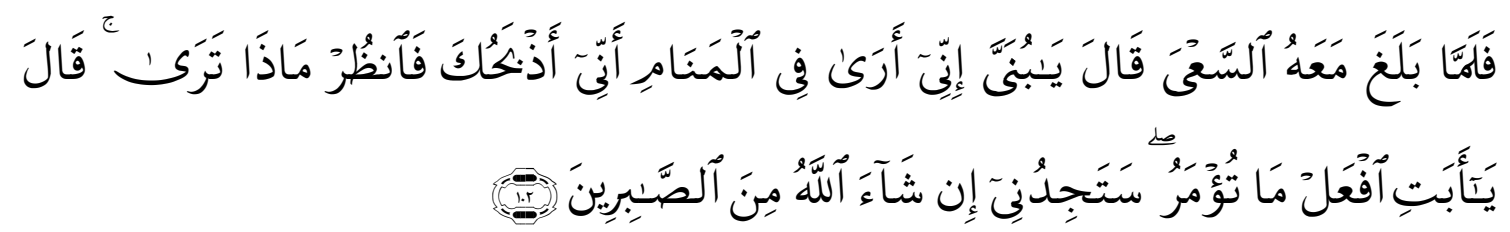

Terjemah: Maka tatkala anak itu sampai (pada umur sanggup) berusaha bersama-sama Ibrahim, Ibrahim berkata: "Hai anakku sesungguhnya aku melihat dalam mimpi bahwa aku menyembelihmu. Maka fikirkanlah apa pendapatmu!" ia menjawab: "Hai bapakku, kerjakanlah apa yang diperintahkan kepadamu, insya Allah kamu akan mendapatiku termasuk orang-orang yang sabar". ${ }^{16}$

Menurut al-Bayḍawìi, potret kisah ini terjadi ketika usia Ismāil sampai pada usia ia layak untuk bekerja, yakni dikisaran usia 13 Tahun. ${ }^{17}$ Usia ini, menurut Granville Stanley, seorang pakar psikologis merupakan fase strom and stress. Fase ini terjadi karena seseorang dapat mengambil keputasannya sendiri, ${ }^{18}$ sehingga dalam masa ini Ismāil sampai pada masa ia dapat mengambil keputasan sendiri. Meskipun dalam beberapa kajian, masa ini merupakan masa ketidakstabilan yang menimpa remaja karena proses pencarian jari dirinya. ${ }^{19}$ Akan tetapi dalam konteks ayat tersebut, keyakinan yang ditampakkan oleh Ismā'ỉl justru menunjukkan kematangan diri dan jiwanya mengenai ketauhidan.

Ketika Ibrāhim menerima perintah dari Allah dalam bentuk mimpi, ia kemudian mengutarakan perintah tersebut kepada Ismāil. Menurut Ibn Kathìr, mimpi yang hadir kepada para Nabi masuk dalam kategori wahyu yang memiliki nilai kebenaran mutlak. Mimpi tersebut sama kualitasnya dengan wahyu yang disampaikan ketika terjaga. ${ }^{20}$ Ketika Nabi Ibrāhìm memperoleh perintah dari Allah unt uk menyembelih Nabi Ismā'îl, perintah tersebut tidak langsung dilakukan. Nabi Ibrāhìm masih menunggu persetujuan dari anaknya. Oleh sebab itu, untuk mendapatkan persetujuan dari Ismā'ìl, Ibrāhīm mengutarakan perihal mimpinya dengan tujuan agar Ismā'ìl tidak terkejut dalam pelaksaan perintah tersebut. begitu juga, penyampaian Ibrāhīm mengenai mimpinya kepada Ismā'ìl juga dalam rangka menguji kesabaran, keteguhan dan keyakinan Ismā'īl kepada Allah dan ketaatannya kepada orang tua. ${ }^{21}$ Berbeda dengan Ibnu Kathïr, Jalāl

\footnotetext{
${ }^{16}$ Q.S. Al-Șäffāt [37]: 102.

${ }^{17}$ Abd Allah bin Umar Al-Bayḍawī, Anwār Al-Tanzīl Wa Asrār Al-Ta’wīl, vol. 5 (Beirut: Dār Iḥyā', al-Turāth al-'Arābī, 1418), 15.

${ }^{18}$ G. Stanley Hall, Adolescence: Its Psychology and Its Relations to Phychology, Antrhropology, Sociology, Sex, Crime, Religion and Education (New York: D. Appleton and Company, n.d.), xiii.

${ }^{19}$ Robert E. Slavin, Educational Psycology: Theory and Practice (New Jersey: Pearson Education, 2000), 11 .

${ }^{20}$ Kathīr, Tafsir Al-Qur'an Al-'Azìim, 7:28.

${ }^{21}$ Kathï, 7:28.
} 
al-Dīn al-Mahalli menyebutkan bahwa tujuan dari nabi Ibrāhim bermusyawarah dengan anaknya disebabkan agar ia patuh dan mau disembelih. ${ }^{22}$

Sedangkan M. Quraish Shihab menyatakan bahwa Nabi Ibrāhim menyampaikan perihal mimpinya kepada anaknya, disebabkan karena ia memahami bahwa perintah tersebut tidak secara nyata dipaksakan kepada anaknya. Dalam pemahaman Ibrāhīm, perintah dalam mimpi tersebut merupakan perintah terhadap dirinya yang harus berkehendak untuk melakukan perintah tersebut. Sedagkan bagi Ismā'íl perintah tersebut adalah ujian bagi dirinya untuk tetap taat mengikuti perintah tersebut atau sebaliknya. Pilihan yang dilakukan Ismā'ìl menurut Shihab, bukan merupakan tanggung jawab Ibrāhim, karena hal tersebut merupakan urusan anaknya dengan Allah. Jika Ismā'il tidak menyetujui atas perintah tersebut, maka ia akan dianggap durhaka kepada Allah dan Ibrāhìm sebagaimana yang menimpa anaknya Nūh. ${ }^{23}$ Penggunaan kata tarā dan tu'mar dengan sighat muḍäri ' mengisyaratkan apa yang dilihat seolaholah masih berlanjut sampai Ibrāhīm menyampaikan mimpi tersebut kepada Ismā'îll. ${ }^{24}$ Sedangkan penggunaan kata adhbahuka mengisyaratkan bahwa mimpi tersebut belum terlaksana dan kewajiban untuk melaksanakannya harus dilakukan segera. ${ }^{25}$

Mendengar perkataan ayahnya, Ismāil langsung menyetujui perintah yang diberikan kepada ayahnya. Jawaban Ismāil dengan menyebutkan mā tu'mar dalam sighat mudări' memberikan pemaknaan bahwa Ismà'íl telah siap menerima perintah tersebut. Redaksi ini juga mengisyaratkan bahwa Ismā'ìl berkeinginan agar ayahnya segera untuk melaksanakan perintah yang berlangsung ataupun perintah yang akan berlangsung. Penggunaan redaksi if'al mā tu'maru (laksanakanlah apa yang diperintahkan kepadamu) bukan adhbihni (sembelihlah aku), dalam pandangan Shihab memberikan pemahaman bahwa penerimaan Ismā'il terhadap perintah tersebut disebabkan karena kepatuhannya kepada Allah, sehingga perintah apapun yang berasal dari Allah akan diterimanya dengan penuh ketaatan dan ketundukan. Penggunaan redaksi ini juga secara bahasa lebih dapat meringankan beban keduanya dalam menghadapi ujian yang diberikan oleh Allah. ${ }^{26}$

Kesabaran Ismāil dalam gambaran ayat tersebut didahului dengan penyebutan kehendak Allah (satajuduni in shä' Allah min al-Ṣäbirin) menandakan bahwa tidak ada keta'atan kecuali atas petunjuk dari Allah dan tidak ada daya untuk melakukan kemaksiatan kecuali karena ada penjagaan dari Allah. ${ }^{27}$ Menurut Shihab, penyebutan kehendak Allah terlebih dahulu menunjukkan integritas dan kemulyaan etika dan moral yang dimiliki Ismā'īl kepada Allah. Intgeritas dan kemulyaan moral yang dimiliki Ismā'ìl merupakan wujud dari pendidikan moral yang diberikan oleh Ibrāhīm menganai

22 Jalāl al-Dīn Al-Shuyūṭi and Jalāl al-Dīn Al-Mahạalli, Tafsīir Al-Jalālayn (Surabaya: al-Hidayah, n.d.), 272.

${ }^{23}$ M. Quraish Shihab, Tafsir Al-Misbah: Pesan, Kesan, Dan Keserasian Al-Qur'an, vol. 6 (Jakarta: Lentera Hati, 2009), 280.

${ }^{24}$ Wahbah Al-Zuhayli, Al-Tafsìr Al-Munìr, vol. 13 (Damaskus: Dār al-Fikr, 1418), 131.

${ }^{25}$ Shihab, Tafsir Al-Misbah: Pesan, Kesan, Dan Keserasian Al-Qur'an, 6:281.

${ }^{26}$ Shihab, 6:281.

${ }^{27}$ Fakr al-Dìn Al-Rāzì, Mafātị̣ Al-Ghayb, vol. 26 (Bairut: Dār al-Fikr, 1981), 157. 
keyakinan dalam hati Ismā'ìl tentang ke-Esaan Allah dan sikap yang pantas diberikan kepada Allah. ${ }^{28}$

\section{Aspek Psikologi Sufistik dalam Komunikasi Intrapersonal Ismāil}

Model teori ini tidak banyak dikenal dan dibahas pada era sebelum abad ke-XX. Terdapat beberapa faktor yang menyebabkan model teori ini tidak banyak diminati, salah satunya adalah ketertarikan para ahli komunikasi terhadap model komunikasi massa. Selain itu, para ahli komunikasi pada era tersebut tidak menganggap komunikasi intrapersonal sebagai bagian dari model komunikasi yang sah, yang memandang bahwa komunikasi harus berjalan melalui emitor dan penerima pesan, sedangkan komunikasi intrapersonal hanyalah bagian dari neologisme. Pada perkembangan selanjutnya, yakni pada pertengahan abad ke-XX, banyak ahli komunikasi mulai memfokuskan kajiannya untuk memberikan konsepsi jelas mengenai komunikasi intrapersonal, misalnya Vocate (1994), Cunningham (1995) and Goss $(1996) .^{29}$

Komunikasi intrapersonal dapat diartikan sebagai bentuk komunikasi yang terjadi dalam diri seseorang atau antara seseorang dengan dirinya sendiri, sehingga komunikasi intrapersonal dapat dimasukkan dalam model berpikir. Meskipun demikian, komunikasi intrapersonal tidak dapat diidentikkan dengan berpikir dalam pengertian ilmiah. Karena jenis berpikir dalam komunikasi intrapesonal tidak memiliki landasan untuk melahirkan sebuah konsep. Berbeda dengan model berfikir ilmiah yang lebih menekankan pada proses penciptaan pesan dan makna, meskipun dialog yang terjadi juga ada dalam diri seseorang. Komunikasi intrapersonal mengandung percakapan yang melibatkan saling bertukar makna antara dua posisi atau mode berpikir di dalam diri seseorang. Didalamnya terkandung pertukaran makna antara entitas dialogis. Hal ini yang membedakan komunikasi intrapersonal dengan perilaku non-verbal, karena didalamnya melibatkan pengunaan bentuk simbolik yang saling dipertukarkan dalam diri seseorang. ${ }^{30}$

Dengan adanya pertukaran makna dan bentuk simbolik dalam komunikasi intrapersonal, proses komunikasi di luar diri seseorang menjadi penting untuk mengetahui seberapa besar rangsangan luar yang diberikan. Larry L. Barker dan Gordon Wiseman berpendapat bahwa sebelum adanya proses pertukaran dalam diri seseorang, terdapat faktor lain yang berpengaruh dalam proses pertukaran tersebut. Mereka kemudian menyimpulkan bahwa dalam komunikasi intrapersonal terdapat dua faktor yang mempengaruhi, faktor eksternal dan faktor internal. Faktor eksternal berhubungan dengan lingkungan komunikator baik hal itu disengaja ataupun tidak

\footnotetext{
${ }^{28}$ Shihab, Tafsir al-Misbah, 281.

${ }^{29}$ Jordi de San Eugenio-Vela, "Approaches to The Study of Individual-Landscape Interaction as an Evocation of Interpersonal Communication," Convergencia 21, no. 64 (2014): 16.

30 Stephen W. Littlejohn and Karen A. Foss, Encyclopedia of Communication Theory, vol. 1 (London: SAGE Publications, 2009), 298.
} 
disengaja. Sedangkan faktor internal berhubungan dengan situasi fisiologis dan psikologis komunikator. $^{31}$

Kesiapan Ismāil dalam menerima perintah penyembelihan juga didorong oleh dua faktor ini. Ismāil yang menerima perintah dari Tuhannya melalui Ibrāhim memberikan respon melalui proses komunikatif dalam dirinya, sehingga akibat proses dialog tersebut, ia kemudian memutuskan untuk menerima perintah baik perintah tersebut langsung dilakukan pada moment tersebut maupun perintah tersebut dilakukan di momen selanjutnya. Keputusan untuk melaksanakan perintah tersebut, tidak terjadi secara "ajaib", karena kesiapan untuk menjalankan perintah bukanlah bagian dari mukjizat yang diberikan Allah kepada Ismā'il. Akan tetapi, kesiapan tersebut didorong oleh ketaatan yang dimiliki, yang dihasilkan dari proses komunikasi dalam diri Ismā'il dengan faktor-faktor pembentuknya. Meskipun, ayat tersebut secara jelas tidak menyiratkan hal demikian, akan tetapi penggunaan redaksi yang digunakan dalam alQur'an yang samar merupakan bagian dari i'jāz al-Qur'an yang harus dicari penjelasnnya. $^{32}$

Proses yang terjadi dalam diri Ismāil melibatkan proses kognitif yang muncul dari responnya dalam menerima kabar dari Ibrāhīm, kemudian mempengaruhi sikap terhadap perintah tersebut (afeksi), hingga akhirnya memunculkan keputusan untuk melaksanakan perintah (konasi). Stratifikasi respon yang dialami dalam diri Ismāil dalam pandangan teori psikologi disebut dengan cognitive respon model (model respon kognitif). ${ }^{33}$ Hal ini dapat diartikan bahwa proses kognitif yang terjadi dalam diri Ismāil merupakan pemaknaan yang muncul diakibatkan adanya respon dari informasi yang diterima dari luar dirinya. ${ }^{34}$ Pemahaman yang dihasilkan oleh Ismāil merupakan bagian dari aspek kognitif yang dapat dipengaruhi oleh pengetahuan maupun pegalaman seseorang di masa lalu. ${ }^{35}$

Pembentukan aspek kognitif dalam diri Ismā'il berlangsung sejak dini, yakni ketika ia masih bayi. Dalam konteks ini, perkembangan respon kognitif yang dimiliki hanya berkaitan dengan sensor motorik yang tumbuh dalam dirinya sebagai respon dari kondisi luar yang dihadapi. ${ }^{36}$ Ismā'il mengalami peristiwa yang diluar kebiasaan ketika ditinggalkan oleh Ibrāhīm di sebuah lembah yang tandus bersama ibunya yang

${ }^{31}$ Larry L. Barker and Gordon Wiseman, “A Model of Intrapersonal Communication,” Jounal of Communication 16, no. 3 (1966): 174.

32 Armainingsih Armainingsih, "Studi Tafsir Saintifik: Al-Jawahir Fi Tafsir Al-Qur'an Al-Karim Karya Syeikh Tantawi Jauhari,” Jurnal At-Tibyan: Jurnal Ilmu Alqur'an Dan Tafsir, vol. 1, 2016, 9798, https://www.journal.iainlangsa.ac.id/index.php/tibyan/article/view/34.

33 Belch.George E. and Michael A. Belch, Advertasing and Promotion: An Intergrated Marketing Communication Perspective (Boston: McGraw-Hill Higher Education, 2001), 160.

${ }^{34}$ Muhammad Faiz Rofdli and Suyadi Suyadi, "TAFSIR AYAT-AYAT NEUROSAINS ("Aql Dalam Al-Qur'an Dan Relevansinya Terhadap Pengembangan Berpikir Kritis Dalam Pendidikan Islam)," JURNAL At-Tibyan Jurnal Ilmu Alquran Dan Tafsir 5, no. 1 (June 30, 2020): 140, https://doi.org/10.32505/tibyan.v5i1.1399.

${ }^{35}$ Susan Nolen-Hoeksema et al., Atkinson \& Hilgard's Introduction to Psychology (Kanada: Nelson Educations Ltd., 2009), 650.

${ }^{36}$ Diane E. Papalia, Sally Wendkos Olds, and Ruth Duskin Feldman, Psikologi Perkembangan, trans. A.K. Anwar (Jakarta: Kencana, 2008), 212. 
mengakibatkannya mengalami kehauasan. Dalam kondisi demikian, Ismā'il memberikan respon atas keadaan tersebut dengan menghentakkan kakinya ke tanah. Akibat dari respon tersebut, kebutuhan Ismā'il terhadap air dapat terpenuhi dengan munculnya sumber mata air. ${ }^{37}$ Dalam proses selajutnya, pembentukan aspek kognitif Ismā'il berlangsung semakin komplek dengan melibatkan satu komunitas masyarakat utuh, yakni Jurhum. ${ }^{38}$

Proses perkembangan yang dialami oleh Ismā'il pada dasarnya melibatkan perkembangan kemampuan intelektual. Dalam kajian psikologi, proses ini disebut sebagai genetic epistimology. ${ }^{39}$ Akan tetapi, perkembangan yang dialami oleh Ismā'il dalam proses pertumbuhanya tidak hanya berkaitan pada aspek perkembangan intelektual, akan tetapi juga pada proses perkembangan spiritual. Kisah mengenai kedatangan Ibrāhìm yang bertemu dengan istrinya, dan menyampaikan pesan tersirat yang mengakibatkan istrinya diceraikan, ${ }^{40}$ merupakan argumentasi yang kuat untuk membuktikan bahwa kematangan diri dan daya tangkap Ismā'il juga berkembang.

\section{Dimensi Sufistik dalam Psikologis Ismā'ìl: Proses Ketaatan dalam Diri}

Dalam konsep tasawuf, perkembangan dalam diri seseorang tidak hanya dipengaruhi oleh pengalaman dan pengetahuan sebelumnya (pre-judices), ${ }^{41}$ akan tetapi terkait erat dengan aspek-aspek lain dalam diri manusia. Perkembangan yang dialami Ismā'il pada dasarnya merupakan perkembangan jiwa dengan memaksimalkan potensi al-rūh (ruh), al-qalb (hati), dan al-'aql (akal). Ruh merupakan entitas yang bersifat potensial yang menentukan eksistensi manusia. ${ }^{42}$ Kesadaran Ismā'il atas posisinya dalam komunitas masyarakat yang terbentuk dengan kehadiran suku Jurhum disekitarnya merupakan kesadaran atas eksistensi dirinya sebagai manusia. Sedangkan qalb adalah elemen dasar setiap manusia yang mampu merasakan, memahami dan mengetahui (haqiqāt al-insān al-mudrik al-ilm). ${ }^{43}$ Begitu juga dengan aql memiliki beberapa pengertian, diantaranya sebagai entitas yang membedakan manusia dengan hewan, kemampuan yang diperoleh melalui pengalaman, dan insting (al-gharizah). ${ }^{44}$ Keduanya merupakan dua hal yang tidak dapat terpisahkan untuk menunjukkan kecerdasan emosional dan kecerdasan intelktual.

Gabungan penggunaan entitas-entitas tersebut akan menghasilkan potensi psikis yang mempengaruhi kecerdasan, kesadaran dan motif seseorang dalam merespon rangsangan dari luar. Gabungan penggunaan aql dengan ruh akan menghasilkan

\footnotetext{
${ }^{37}$ Muhammad bin Jarīr Al-Ṭabari, Tärikh Al-Ṭabari, vol. 1 (Beirut: Dār al-Turāth, 1387), 247.

${ }^{38}$ Muhammad bin Muhammad Ibn Athīr, Al-Kāmil Fì Al-Tārikh, vol. 1 (Beirut: Dār al-Kutub al'Ilmiyah, 1987), 80.

${ }^{39}$ Howard S. Friedman and Miriam W. Schustack, Kepribadian: Teori Klasik Dan Riset Modern, trans. Fransiska Dian Ikarini, Maria Hany, and Andreas Provita Prima (Jakarta: Erlangga, 2006), 59.

${ }^{40}$ Ibn Athīr, Al-Kämil Fì Al-Tärikh, 1:80.

${ }^{41}$ Hans-Georg Gadamer, Truth and Method, trans. Joel Weinsheimer and Donald G. Marshall (London: Continuum, 2006), 390.

${ }^{42}$ Abū Hāamid Al-Ghazāli, Ihyā', Ulūm Al-Dīn, vol. 3 (Beirut: Dār al-Fikr, n.d.), 4-5.

${ }^{43}$ Al-Ghazāli, 3:4-5.

${ }^{4}$ Al-Ghazāili, 1:101-2.
} 
kemampuan psikis yang rasional-emosional. Sedangkan hati merupakan pengontrol untuk menstabilkan dimensi ruhaniyah (emosional) dengan dimensi aqliyah (rasionalitas). Hati sebagai temapat muara pengetahuan yang bersumber dari Tuhan, memungkinkannya untuk mendapatkan pengetahuan murni yang diperoleh melalui ilhām dan mukasyafah. ${ }^{45}$ Untuk memberikan kestabilan pada ruh dan aql, hati dilengkapi dengan entitas yang disebut dengan junūd al-qalb (tentara hati). ${ }^{46}$

Respon Ismāil terhadap perintah Allah melalui Ibrāhīm untuk disembelih diterima dengan sikap kepasrahan atas perintah tersebut. Sikap ini pada dasarnya banyak dipengaruhi oleh pendidikan yang diberikan kepada Ismā'il mengenai keTuhanan dan keyakinannya kepada Tuhan. Keyakinan tersebut diperoleh Ismā'ìl dari pendidikan yang diberikan oleh Ibrāhīm. Dalam beberapa literatur sejarah, sebelum terjadinya perintah penyembelihan, Ismā'īl terlibat langsung dalam proses pembangunan kembali Ka'bah yang dilakukan oleh Ibrāhīm. Hal ini dapat dijadikan indikasi bahwa Ismā'îl, sejak awal dikenalkan oleh Ibrāhīm mengenai keyakinankeyakinan spiritual yang dianutnya. ${ }^{47}$

Akumulasi kematangan jiwa Ismā'il yang dihasilkan dari kematangan perkembangan rūh, al-qalb, dan al-aql secara bersamaan, menumuhkan dimensi rūhaniyah dalam memberikan konsep-konsep keyakinan spiritual dalam dirinya, ${ }^{48}$ sehingga meyakini bahwa perintah yang diberikan oleh Ibrāhim berasal dari Allah. Sedangkan respon yang dilakukan oleh Ismā'ill secara aqliyah dipengaruhi oleh konsepkonsep keyakinan yang ditanmakn oleh Ibrāhīm kepada Ismā'îl mengenai keimanan. Respon ini tergambar jelas dengan penggunaan kata al-sa'y untuk menunjukkan kesiapan Ismā'îl dalam menjalankan perintah.

Kesiapan (al-sa'y) dapat dialihkan pemaknaannya tidak pada hitungan usia, akan tetapi pada proses kesempurnaan pembentukan aspek kognitif dalam diri seseorang yang tercermin dalam entitas-entitas jiwa. Dalam hal ini kecerdasan intelektual ( 'aqI) tidak dapat dipisahkan dengan kecerdasan emosional (al-qalb) yang bersatu dalam diri seseorang (al-nafs). Ismā'îl dinilai siap melaksanakan perintah ketika ia mampu secara emosional dan intelektual untuk mempertimbangkan simbol-simbol yang dihantarkan oleh Ibrāhīm dalam proses komunikasinya. ${ }^{49}$ Kesiapan dalam arti yang lebih luas dapat di identifikasi dengan capaian pemahaman yang terbuka yang menjadikan manusia

\footnotetext{
${ }^{45}$ M. Ulil Abshor, "Penafsiran Sufistik KH. Shalih Darat Terhadap Q.S. Al-Baqarah: 183,” Jurnal Studi Ilmu-Ilmu Al-Qur'an Dan Hadis 19, no. 2 (October 13, 2019): 203, https://doi.org/ 10.14421/qh.2018.1902-05.

46 Abū Hāmid Al-GhazāTi, Rawḍat Al-Ṭālibīn Wa Umdah Al-Sālikin (Beirut: Dār al-Nahdah alHadithah, n.d.), 62; Ahmad Azrin Adnan, "Pandangan Pakar Terhadap Penentu Pemilihan Bank Menurut Muslim Ideal: Perspektif Intrinsik," International Journal of Islamic Thought 3, no. 1 (June 1, 2013): 20, https://doi.org/10.24035/ijit.03.2013.002.

${ }^{47}$ Muhammad bin Jarìr Al-Ṭabari, Tārikh Al-Ṭabarî, vol. 1 (Beirut: Dār al-Turāth, 1387), 251.

${ }^{48}$ Salina Nen et al., "Tahap Keyakinan Diri Bekas Penagih Dadah Dalam Pengawasan Di Malaysia: Ke Arah Kepulihan Menyeluruh (Self-Esteem Among Former Drug Addicts Under Observation In Malaysia: Towards A Comprehensive Recovery)," Jurnal Psikologi Malaysia 31, no. 1 (2017), http://spaj.ukm.my/ppppm/jpm/article/view/246.

${ }^{49}$ al-Ghazāil, Ihyā' Ulüm al-Dīn, I/ 101-102.
} 
secara bebas memikirkan segala wujud yang ada diluarnya. Disamping itu, ia mampu mengetahui, mengenal diri sendiri dan mempersepsikan keadaan yang ada dalam realitas, sehingga jiwa dapat memproyeksikan dan mengafirmasi segala yang yang ditangkap oleh panca indera secara alami. ${ }^{50}$

Proses pencapaian terhadap level al-sa'y tidak diperoleh secara taken from granted, akan tetapi melalui proses panjang yang melibatkan fisik dan psikis Ismā'īl agar dapat menerima perintahnya dengan tanpa memikirkan terlebih dahulu (if'al ma tu'mar). Proses pembentukan ini dimulai sejak Ismā'il masih bayi, yang kemudian dilanjutkan dengan peristiwa-peristiwa lain yang membangun aspek kognitifnya. Peristiwa yang dapat menjadi contoh adalah kedatangan Ibrāhīm setelah lama berpisah dengan Ismā'ìl. Pada saat kunjungannya ke Makkah, Ibrāhīm mengetahui bahwa Sarah telah meninggal, kemudian ia langsung menuju ke rumah Ismā'ìl dan bertemu dengan istrinya. Ia kemudian menitipkan salam kepada isti Ismā'îl untuk disampaikannya. Ibrāhīm memerintahkan kepada istri Ismā'îl untuk mengganti daun pintu rumahnya. Pemberian isyarat semacam ini, sebagai bagian dari simbol yang diberikan kepada Ismā'ìl untuk mengganti istrinya. ${ }^{51}$ Dengan pemahaman yang cepat atas isyarat tersebut, Ismā'ìl memiliki kepatuhan atas perintah-perintah yang diberikan oleh Ibrāhìm, meskipun dalam kadar kemampuan manusia biasa hal tersebut tidak masuk akal.

Peristiwa-peristiwa pendahuluan yang berfungsi untuk membentuk kesiapan Ismā'ìl yang ditunjukkan dengan redaksi al-sa'y berperan dalam memantapkan dan mematangkan emosi dan kesadaran religius Ismā'il sebelum menerima perintah, sehingga kata al-sa'y, lebih tepat digunakan untuk tidak menunjukkan pada usia. ${ }^{52} \mathrm{Hal}$ demikian dapat dilihat dari penjelasan kejadian penyembelihan dalam berbagai literatur sejarah disebut setelah menyebutkan peristiwa-peristiwa tersebut diatas. ${ }^{53}$ Jika perkiraan umur yang disebutkan oleh beberapa mufassir mendekati kebenaran, maka pengalaman pernikahan yang disebutkan dalam beberapa literatur sejarah juga dapat dibenarkan. ${ }^{54}$ Hal ini disebabkan karena terdapat banyak perselisihan dalam penentuan umur Ismā'il dalam peristiwa tersebut.

Terlepas dari kepastian usia Ismā'il dalam peristiwa tersebut, perkembangan yang ditunjukkan olehnya, baik secara psikis dan fisiologis, mempengaruhi terhadap kemampuan-kemampuannya dalam memahami secara langsung terhadap hal-hal praksis. Dalam konteks ini, al-Ghazāli membagi proses pemahaman tersebut dalam dua

\footnotetext{
${ }^{50}$ Abū Ḥāmid Al-Ghazāii, Mi'yār Al-'Ilmīi (Mesir: Dār al-Ma'arif, 1961), 287.

${ }^{51}$ Muhammad bin Muhammad Ibn Athīr, Al-Kāmil Fì Al-Tārikh, vol. 1 (Beirut: Dār al-Kutub al'Ilmiyah, 1987), 80-81.

${ }^{52}$ Al-Zuhayli, Al-Tafsir Al-Munir, 23:118.

${ }^{53}$ Lihat Ibn Athīr, Al-Kämil Fì Al-Tārikh; Al-Ṭabari, Tärikh Al-Tabarī.

${ }^{54}$ Wely Dozan, "Analisis Pergeseran Shifting Paradigm Penafsiran: Studi Komparatif Tafsir Era Klasik Dan Kontemporer," Jurnal At-Tibyan Jurnal Ilmu Alquran Dan Tafsir 5, no. 1 (June 30, 2020): 45, https://doi.org/10.32505/tibyan.v5i1.1631.
} 
bagian, yakni al-aql al-amali (akal praksis) dan al-aql al-naḍari (akal teoritis). ${ }^{55}$ Pengetahuan mengenai ke-Tuhanan diperoleh oleh Ismā'îl secara praksis dengan petunjuk-petunjuk yang diberikan Ibrāhīm kepadanya sebelum terjadinya peristiwa penyembelihan tersebut. Sedangkan pengetahuan teoritis dapat diperoleh melalui alaql al-ghärizí (insting) dan al-aql al-muktasab (ilham). Kedua pengetahuan terbentuk secara pribadi dalam diri Ismā'íl. al-Aql al-ghārizī merupakan kemampuan rasionalitas dari diri seseorang untuk menerima pengetahuan, sedangan al-'aql al-muktasab merupakan pengetahuan yang diperoleh karena faktor ketataatan dan kepatuhan seseorang kepada Tuhan. ${ }^{56}$

Korelasi antara keyakinan rühaniyah dan rasionalitas pengetahuan yang dimiliki oleh Ismā'il distabilisasikan dengan kekuatan atau daya yang dimiliki oleh al-qalb. Hati merupakan elemen dasar yang mampu memberikan pengetahuan (haqiqät al-insān al-mudrik al-ilm). ${ }^{57}$ Karena sifat yang demikian, hari merupakan pusat dari aktivitas manusia baik jasmani maupun ruhani. ${ }^{58}$ Dalam proses fungsinya sebagai stabilizer, hati dilengkapi oleh jaringan-jaringan yang fungsinya dapat dibagi menjadi tiga. Pertama adalah al-irädah (kehendak) yang mampu mendorong tindakan yang dapat memberikan manfaat, serta dapat mencegah tindakan yang mendatangkan bahaya. Kedua, al-qudrah (kemampuan) yang mampu mendorong anggota tubuh untuk merealisasikan kehendak yang dituju oleh al-irādah. Ketiga, al-'ilm wa al-idrāk (pengetahuan dan pemahaman) yang dapat memberikan pengetahuan dan pemahaman terhadap segala sesuat . $^{59}$

Jaringan-jaringan tersebut diletakkan dalam setiap panca indera sesuai dengan fungsinya masing-masing. Jaringan ini juga diletakkan dalam akal, yang dapat mengontrol potensi-potensi yang ada dalam akal, seperti kekuatan menghafal, imajinasi, dan kekuatan rasional. ${ }^{60}$ Kontrol yang diberikan oleh hati terhadap kemampuan akal, mengindikasikan bahwa keduanya memiliki kaitan dan relasi yang sejalan. Hati memberikan tuntunan dan klarifikasi atas potensi-potensi yang dimiliki akal, sehingga dapat berjalan sesuai dengan kehendak dalam hati. Pengetahuan sebagai hasil dari proses kognitif dalam psikologi sufistik memberikan hubungan yang intim antara hari, akal dan jiwa tanpa memberikan perubahan dalam sikap seseorang. ${ }^{61}$ Respon atas tindakan yang melibatkan akal dan jiwa, dapat didorong oleh hati. Oleh sebab itu, kecepatan respon yang dihasilkan oleh akal dan jiwa dapat dikontrol melalui hati. Semakin bersih hati seseorang, maka akan semakin cepat dalam memberikan respon atas rangsangan yang diperolehnya dari luar.

\footnotetext{
${ }^{55}$ Abū Ḥāmid Al-GhazāTi, Ma’ārij Al-Quds Fì Madārij Ma’rifah Al-Nafs (Kairo: Maktabah al-Jund, 2968), 67.

${ }^{56}$ Abū Hāamid Al-GhazāTi, Mizān Al-Amal (Mesir: Dār al-Ma'arif, 1964), 337.

${ }^{57}$ Zahra Alafchian and Mohammad Reza Shamshiri, "The Will and Free Will According to Ghazali and Spinoza," Comparative Theology 9, no. 19 (May 22, 2018): 1-22, https://doi.org/10.22108/COTH.2018.80269.0.

58 Al-Ghazāil, Ihyā', Ulüm Al-Dìn, 3:4.

59 Al-Ghazāili, Rawḍt Al-Ṭālibīn Wa Umdah Al-Sālikin, 62.

${ }^{60}$ Al-Ghazāli, 63.

${ }^{61}$ Ebrahim Moosa, Ghazali Dan Seni Imajinasi Sufistik, trans. Abdul Kadir Riyadi and Ahmad Kahfi (Surabaya: IMTIYAZ, n.d.), 279.
} 
Dalam psikologi sufistik, fungsi kognitif seseorang tidak hanya didasarkan pada pemahaman dalam satu aspek pengetahuan. Akan tetapi melibatkan pemahaman dimensi religiutas dengan menyertakan seluruh pengalaman rasional dan emosional terhadap rangsangan yang diterimanya dari luar. Respon ini diolah sedemikian rupa sehingga mempengaruhi terhadap sikap seseorang atas rangsangan tersebut. Pertimbangan yang dihasilkan dalam proses komunikasi dalam diri Ismā'īl menjadikanya menerima permintaan Ibrāhīm untuk melakukan penyembelihan. Sikap afektif Ismā'ìl tampak dalam penggunaan redaksi if'al mā tu'maru (laksanakanlah apa yang diperintahkan kepadamu). Penggunaan redaksi ini menurut Quraish Shihab mengisyaratkan kepatuhan Ismā'il atas perintah Allah yang disampaikan pada Ibrāhìm, sehingga perintah dalam bentuk apapun dan sesulit apapun akan dilaksanakan secara patuh dan tunduk. Penggunaan redaksi ini pula mengindikasikan bahwa ujian yang dihadapi Ibrāhīm dan Ismā'ìl merupakan ujian yang berat, sehingga pemilihan redaksi yang tepat dapat meringankan keduanya dalam melaksanakan ujian tersebut. ${ }^{62}$

Proses afektif ini menghasilkan tampilan daya-daya psikis dalam bentuk tingkah laku dengan penerimaan atas perintah penyembelihan. Kesabaran Ismāil dalam menerima keputusan tersebut tergambar dalam ayat tersebut dengan didahului penyebutan kehendak Allah (satajuduni in shä' Allah min al-Șābirin) yang menandakan bahwa tidak ada keta'atan kecuali atas petunjuk dari Allah dan tidak ada daya untuk melakukan kemaksiatan kecuali karena ada penjagaan dari Allah. ${ }^{63}$ Menurut Shihab, penyebutan kehendak Allah terlebih dahulu menunjukkan kemulyaan moral yang dimiliki oleh Ismā'ìl yang diperolehnya dari Ibrāhīm. Hal ini juga mengindikasikan bahwa pemahaman dan keyakinan Ismā'íl terhadap Allah, telah ditanamkan sejak dini dengan menguatkan aspek-aspek ketauhidan dan moralitas dalam bersikap kepada Allah. ${ }^{64}$

\section{Konsep Kebenaran Psikologi Sufistik dalam Komunikasi Intrapersonal Ismāil}

Tindakan yang dilakukan seseorang dalam konteks sosialnya, pada dasarnya dipengaruhi oleh dorongan-dorongan dari dalam diri yang menjadi sumber tindakan tersebut. Dorongan-dorongan tersebut berlaku secara umum, karena dorongan tersebut bersifat taken from granted (anugrah). Bahkan dalam kajian psikologi, dikenal istilah sociobiologis yang bertujuan mendeteksi sumber-sumber biologis dalam diri manusia yang menjadi sumber dari tingkah laku manusia. ${ }^{65}$ Demikian halnya dalam tasawuf yang menjadi dasar dari psikologi sufistik.

Dalam tasawuf, sumber pengetahuan dapat diperoleh dari pengetahuan intuitif yang bersumber dari dhauq, ilham dan intuisi. Pengetahuan intuitif dapat dihasilkan melalui pengamatan langsung dengan penekanan pada hakikat kebenaran objek

\footnotetext{
${ }^{62}$ Shihab, Tafsir Al-Misbah: Pesan, Kesan, Dan Keserasian Al-Qur'an, 6:281.

${ }^{63}$ Fakr al-Dìn Al-Rāzì, Mafătị̆ Al-Ghayb, vol. 26 (Bairut: Dār al-Fikr, 1981), 157.

${ }^{64}$ Shihab, Tafsir Al-Misbah: Pesan, Kesan, Dan Keserasian Al-Qur'an, 15:281.

65 Jean Walter MacCluer, "The Sociobiology Debate," Contemporary Psichology: A Journal of Reviews 25, no. 5 (1980): 385-86.
} 
pengamatan. ${ }^{66}$ Meskipun demikian, pengetahuan ini bersifat terbatas, karena kesimpulan yang dihasilkan tidak ditempuh melalui penyimpulan logis atas susunan premis-premis, akan tetapi melalui pengalaman religius dan menajaman potensi hati. Pendalaman atas sumber pengetahuan intiuitif dihasilkan oleh kemampuan dalam merespon seseuatu secara mendalam yang berkaitan dengan dimensi batin.

Dalam pandangan Ibn 'Arabi, pengetahuan dapat diperoleh dengan menggunakan dua sumber pengetahuan, yakni al-ma'rifah dan al-'ilm. Al-Ma'rifah merupakan pengetahuan yang dihasilkan dengan pengenalan secara langsung yang berkaitan dengan nafs (jiwa) dan qalb (hati). Sedangkan al-ilm adalah pengetahuan yang bersumber dari penalaran logis mengenai sesuatu, sehingga melibatkan al-aql. ${ }^{67}$ Akal dan intuisi merupakan dua hal yang saling berdealektika. Javad Nurbakh dalam Sufism and Psicologianalisis mengaitkan keduanya dengan menggunakan istilah aql juz' $\bar{i}$ (partikular) dan aql kulli (universal). ${ }^{68}$ Akal partikular memperoleh pengetahuan dari pengalaman-pengalaman yang dihasilkan akibat adanya interaksi seseorang dengan realitas di luar dirinya. Akal partikural tidak dapat digunakan untuk mecapai kebenaran, karena kebenaran selalu berkaitan dengan keseluruhan. Kebenaran dalam psikologi sufistik menurut Javad hanya diperoleh melalui intuisi yang ditanggkap oleh akal universal. ${ }^{69}$

Dalam kaitan kisah penyembelihan Ismā'ill, kebenaran perintah Ibrāhīm kepadanya tidak dihasilkan dari pengetahuan-pengetahuan yang bersumber dari akal, akan tetapi diperolehnya melalui pengetahuan intuitif yang muncul dari dalam dirinya. Pengetahuan intuitif ini dapat diperoleh oleh seseorang yang memiliki kebersihan hari dan kekuatan jiwa. ${ }^{70}$ Meskipun demikian, pengetahuan intutuitif mengenai kebenaran perintah tersebut, juga berkaitan langsung dengan pengalaman-pengalaman langsung yang dialami oleh Ismā'îl ketika berinteraksi langsung dengan Ibrāhīm. Dalam konteks ini, akal juga memberikan rangsangan bagi pengetahuan intuitif mengenai esensi kebenaran dari perintah tersebut. al-GhazāTi memberikan penjelasan bahwa fungsi akal dalam tasawuf adalah memberikan jalan dan konsepsi berfikir yang benar, sehingga seseorang dapat mempersiapkan diri untuk memperoleh pengetahuan intuitif dari Tuhan. $^{71}$

Perintah penyembelihan dalam Q.S. al-Săffāt [37]: 102, tidak dipahami sebagai redaksi perintah yang bersifat majazi (metafora). Perintah ini diyakini sebagai kalimat dengan redaksi haqiq $\bar{i}$ (jelas). Hal ini berarti, permintaan Ibrāhīm kepada Ismā'īl

${ }^{66}$ Sanem Soyarslan, "The Distinction between Reason and Intuitive Knowledge in Spinoza's Ethics," European Journal of Philosophy 24, no. 1 (March 1, 2016): 27-54, https://doi.org/10.1111/ ejop. 12052 .

${ }^{67}$ Abu al-'Ala Afifi, Filsafat Ilmu Mistik Ibn 'Arabi, trans. Syahrir Nawawi and Nandi Rahman (Jakarta: Gaya Media, 1989), 148.

${ }^{68}$ Milad Milani, Sufi Politics in the Contemporary West : The Role and Definition of Sufism in the Works of Javad Nurbakhsh (1926-2008), 2017.

${ }^{69}$ Javad Nur Bakhsah, "Tasawuf Dan Psikoanalisa Konsep Iradah Dan Transferensi Dalam Psikologi Sufi," Ulumul Quran, no. 8 (1991).

${ }^{70}$ Al-Ghazāli, Ihyā' Ulüm Al-Dìn, 3:18-20.

${ }^{71}$ Abū Ḥāmid Al-Ghazāli, Mishkah Al-Anwār (Kairo, 1964), 207. 
mengenai penyembelihan atas dirinya dimaksudkan secara jelas, yakni dengan cara penyembelihan sebagaimana diketahui secara umum. ${ }^{72}$ Respon yang ditunjukkan Ismā'il menandakan bahwa ia meyakini bahwa permintaan yang dilakukan oleh Ibrāhīm benar-benar bersumber dari Allah dengan menggunakan redaksai if'al mā tu'mar. ${ }^{73}$ Keyakinan terhadap kebenaran perintah tersebut tidak hanya didasarkan pada pengetahuan intuitif semata, akan tetapi juga diyakini secara ruhaniyah dan aqliyah. Dimensi ruhaniyah dalam penalaran kognitif mengetahui bahwa kepatuhan dan ketundukan kepada Tuhan merupakan hal yang alamiyah yang dimilikinya semenjak lahir. Begitu juga, keyakinan kebenaran terhadap permintaan Ibrāhìm juga bersumber dari keyakinannya atas sumber permintaan tersebut berasal dari Tuhan. Keyakinan ini diperoleh dari pengalaman yang dialami Ismā'ìl dalam berinteraksi dengan Ibrāhīm.

Konsepsi kebenaran dalam psikologi tasawuf, tidak hanya didasarkan atas satu aspek. Akan tetapi, kebenaran tersebut telah divalidasi oleh seluruh aspek yang membentuk unsur kognisi manusia. Hati sebagai pusat dan wadah dari pengetahuan intuitif, ${ }^{74}$ membutuhkan akal sebagai saran untuk mengantarkannya dalam memperoleh pengetahuan intuitif tersebut. Begitu juga dengan jiwa sebagai tempat dan sarana bagi manusia mengetahui eksisistensinya. Relasi ketiganya tidak berjalan searah, akan tetapi ralasi yang dibentuk antara hati, akal dan ruh bersifat singular. Hati melalui pengetahuan intuitifnya dalam batas tertentu dikontrol oleh akal sebagai sarana pengujian dan penilaian kritis terhadap pengalaman-pengalaman sufistik seseorang. Begitu juga dengan ruh yang dapat menentukan dan mengabaikan eksistensi dirinya dalam kehidupan sosial seseorang.

Bahkan, Harold H. Titus berpendapat bahwa intuisi pada dasarnya hanya merupakan hasil tumpukan pengalaman dan pemikiran seseorang di masa lalu. Intuisi ini merupakan hasil dari penalaran indukitif dan deduktif seseorang terhadap pemandekan pengetahuan yang seharusnya diungkapkan oleh indera dan pemikiran reflektif di bawah sadar. Oleh sebab itu, dalam literatur modern, intuisi disamakan dengan penalaran cepat, imanjinasi, pemikiran yang ringkas dan pertimbangan yang sehat. Hal ini dapat ditemukan pembuktiannya dari banyaknya pandangan ilmiah yang tajam dan cepat, dihasilkan oleh orang yang memiliki pengalaman dan intensitas yang tinggi terhadap berbagai problem ilmiah. ${ }^{75}$ Intensitasi yang dialami oleh Ismā'īl dalam sejarah kehidupannya terhadap ketakwaan, menjadikannya dapat berpikir dengan cepat dan merespon perintah Ibrāhim dengan keyakinan penuh.

\footnotetext{
${ }^{72}$ Shihab, Tafsir Al-Misbah: Pesan, Kesan, Dan Keserasian Al-Qur'an, 6:281.

${ }^{73}$ Shihab, 6:281.

${ }^{74}$ Sansan Ziaul Haq, "Hermeneutika Sufistik: Telaah Epistemologi Takwil Ibn 'Arabi," Jurnal AtTibyan: Jurnal Ilmu Alquran Dan Tafsir 4, no. 1 (July 27, 2019): 17, https://doi.org/10.32505/ tibyan.v4i1.890.

${ }^{75}$ Harold H. Titus, Persoalan-Persoalan Filsafat (Jakarta: Bulan Bintang, 1984), 204-5.
} 


\section{Penutup}

Dialog antara Nabi Ibrāhīm dengan anaknya yang terekam dalam Q.S. al-Sāffāt [37]: 102 berkaitan dengan perintah yang didapatkan oleh Ibrāhīm dari Allah untuk melakukan penyembelihan kepada Ismā'ìl. Beberapa kalangan sejarawan maupun ulama' tafsir memiliki banyak pandangan mengenai anak yang dimaksud dalam ayat tersebut. Mayoritas ulama' menegaskan bahwa anak yang dimaksudkan adalah Nabi Ismā'ill. Nabi Ismā'íl menerima perintah tersebut tanpa adanya paksaan dari Nabi Ibrāhīm, sehingga banyak kalangan menyebutkan bahwa kisah yang diceritakan dalam ayat tersebut merupakan gambaran pendidikan ideal terhadap anak. Akan tetapi, kandungan yang makna yang lebih mandalam dalam kisah tersebut adalah sikap yang ditunjukkan oleh Nabi Ismā'il untuk menerima perintah tersebut tanpa mempersoalkan alasan dibalik penyembelihan.

Keputusan Nabi Ismā'ìl dalam menerima perintah tersebut, pada dasarnya dipengaruhi oleh komunikasi intrapersonal yang terjadi dalam dirinya. Komunikasi intrapersonal dalam diri Ismāil melibatkan proses kognitif yang muncul dari responnya dalam menerima kabar dari Ibrāhīm, kemudian mempengaruhi sikap terhadap perintah tersebut, hingga akhirnya memunculkan keputusan untuk melaksanakan perintah. Dalam konteks psikologi sufistik, proses kognitif yang terjadi dalam diri Ismā'ìl melibatkan entitas-entitas diri yang dibetuk oleh al-rūh (jiwa), al-'aql (rasio), dan alqalb (hati). Ketiga entitas sebagai pembentuk pemahaman dalam diri Ismā'īl terproyeksikan dalam sikapnya untuk menerima perintah sebagai bagian dari ketaatannya terhadap Tuhan.

Keyakinan atas kebenaran perintah, muncul dari pemahamannya yang bersifat intuitif yang dihasilkan dari akumulasi pengetahuan yang diperoleh oleh jiwa, rasio, dan hati dengan epistemnya sendiri. Pengalaman Ismā'il dalam melakukan interkasi dengan Ibrāhīm merupakan sumber pengetahuan yang dicapai oleh rasio mengenai kepatuhan atas perintah Tuhan. Begitu juga, kebersihan jiwa dan ketaatannya kepada Tuhan menjadikan hatinya dapat menerima pengetahuan intuitif yang berasal dari Tuhan. Dengan pengetahuan-pengetahuan tersebut, Ismā'il memberikan respon atas perintah Tuhan yang diberikan kepada Ibrāhīm dengan penerimaan sepenuhnya. Respon ini berjalan tidak secara ajaib, akan tetapi melewati proses panjang yang terbentuk dalam sejarah kehidupan Ismā'ìl sejak kecil. 


\section{DAFTAR PUSTAKA}

Abshor, M. Ulil. "Penafsiran sufistik KH. Shalih Darat Terhadap Q.S. Al-Baqarah: 183." Jurnal Studi Ilmu-Ilmu Al-Qur'an Dan Hadis 19, no. 2 (October 13, 2019): 203. https://doi.org/10.14421/qh.2018.1902-05.

Adnan, Ahmad Azrin. "Pandangan Pakar Terhadap Penentu Pemilihan Bank Menurut Muslim Ideal: Perspektif Intrinsik." International Journal of Islamic Thought 3, no. 1 (June 1, 2013): 18-36. https://doi.org/10.24035/ijit.03.2013.002.

Afifi, Abu al-'Ala. Filsafat Ilmu Mistik Ibn 'Arabi. Translated by Syahrir Nawawi and Nandi Rahman. Jakarta: Gaya Media, 1989.

Al-Bayḍawī, Abd Allah bin Umar. Anwār Al-Tanzīl Wa Asrār Al-Ta'wìl. Vol. 1. Beirut: Dār Ihyā̄' al-Turāth al-'Arābī, 1418.

Al-Ghazāii, Abū Ḥāmid. Ihyā' Ulūm Al-Dīn. Vol. 3. Beirut: Dār al-Fikr, n.d.

—. Ma'ārij Al-Quds Fì Madārij Ma’rifah Al-Nafs. Kairo: Maktabah al-Jund, 2968.

—. Mi'yār Al-'Ilmī. Mesir: Dār al-Ma'arif, 1961.

-. Mishkah Al-Anwär. Kairo, 1964.

Mizān Al-Amal. Mesir: Dār al-Ma'arif, 1964.

- Rawḍat Al-Tālibīn Wa Umdah Al-Sālikin. Beirut: Dār al-Nahdah al-Hadithah, n.d.

Al-Qaț̣ān, Mannā' Khađill. Mabāhith Fỉ Ulūm Al-Qur'an. Riyāḍ: Manshūrāt al-'Aṣr alHadith, 1973.

Al-Rāzìi, Fakr al-Dīn. Mafătiḥ Al-Ghayb. Vol. 5. Bairut: Dār al-Fikr, 1981.

Al-Shuyūtịi, Jalāl al-Dīn, and Jalāl al-Dīn Al-Maḥalli. Tafsìr Al-Jalālayn. Surabaya: alHidayah, n.d.

Al-Ṭabarì, Muḥammad bin Jarìr. Jāmi' Al-Bayān Fì Ta’wīl Al-Qur'an. Vol. 5. Bairut: Muassasah al-Risālah, 2000.

Tärikh Al-Tabarì. Vol. 1. Beirut: Dār al-Turāth, 1387.

Al-Zuhayli, Wahbah. Al-Tafsìr Al-Munïr. Vol. 2. Damaskus: Dār al-Fikr, 1418.

Alafchian, Zahra, and Mohammad Reza Shamshiri. "The Will and Free Will According to Ghazali and Spinoza." Comparative Theology 9, no. 19 (May 22, 2018).

Armainingsih, Armainingsih. "Studi Tafsir Saintifik: Al-Jawahir Fi Tafsir Al-Qur'an Al-Karim Karya Syeikh Tantawi Jauhari." Jurnal At-Tibyan: Jurnal Ilmu Alqur'an Dan Tafsir. Vol. 1, 2016.

Aulia, Rahmadianti. "Peran Ayah Dalam Pengasuhan: Tinjauan Kisah Nabi Ibrahim Dan Nabi Ismail Dalam Al-Qur'an.” Al-Qalb : Jurnal Psikologi Islam. Vol. 8, 2017. https://doi.org/10.15548/ALQALB.V8I2.875.

Bakhsah, Javad Nur. "Tasawuf Dan Psikoanalisa Konsep Iradah Dan Transferensi Dalam Psikologi Sufi." Ulumul Quran, no. 8 (1991).

Barker, Larry L., and Gordon Wiseman. "A Model of Intrapersonal Communication." Jounal of Communication 16, no. 3 (1966).

Budihardjo, Budihardjo. "Pendidikan Nabi Ibrahim Dan Anaknya Dalam Perspektif Al- 
Qur'an (Q.S. Al-Shafat [37]: 102 - 107).” Millah 9, no. 2 (February 15, 2010): 191-206. https://doi.org/10.20885/millah.vol9.iss2.art2.

Dozan, Wely. "Analisis pergeseran shifting paradigm penafsiran: studi komparatif tafsir era klasik dan kontemporer." Jurnal At-Tibyan Jurnal Ilmu Alquran Dan Tafsir 5, no. 1 (June 30, 2020): 37-55.

E., Belch.George, and Michael A. Belch. Advertasing and Promotion: An Intergrated Marketing Communication Perspective. Boston: McGraw-Hill Higher Education, 2001.

Eugenio-Vela, Jordi de San. "Approaches to The Study of Individual-Landscape Interaction as an Evocation of Interpersonal Communication." Convergencia 21, no. 64 (2014).

Falah, Saiful. "Pendidikan Karakter Berbasis Keluarga Pada Kisah Nabi Ibrahim Dan Ismail.” Ta’dibuna: Jurnal Pendidikan Islam 9, no. 1 (April 30, 2020): 133.

Friedman, Howard S., and Miriam W. Schustack. Kepribadian: Teori Klasik Dan Riset Modern. Translated by Fransiska Dian Ikarini, Maria Hany, and Andreas Provita Prima. Jakarta: Erlangga, 2006.

Gadamer, Hans-Georg. Truth and Method. Translated by Joel Weinsheimer and Donald G. Marshall. London: Continuum, 2006.

Hall, G. Stanley. Adolescence: Its Psychology and Its Relations to Phychology, Antrhropology, Sociology, Sex, Crime, Religion and Education. New York: D. Appleton and Company, n.d.

Haq, Sansan Ziaul. "Hermeneutika Sufistik: Telaah Epistemologi Takwil Ibn 'Arabi." Jurnal At-Tibyan: Jurnal Ilmu Alquran Dan Tafsir 4, no. 1 (July 27, 2019): 125. $\mathrm{h}$

Hasan, Zainol. "Nilai-nilai pendidikan islam pada kisah nabi ibrahim." NUANSA: Jurnal Penelitian Ilmu Sosial Dan Keagamaan Islam 14, no. 2 (March 1, 2018): 423. https://doi.org/10.19105/nuansa.v14i2.1642.

Ibn Athīr, Muhammad bin Muhammad. Al-Kāmil Fì Al-Tārikh. Vol. 1. Beirut: Dār alKutub al-'Ilmiyah, 1987.

Kathīr, Ismāil bin Umar bin. Tafsìr Al-Qur'an Al-'Azìm. Vol. 8. Beirut: Dār alTayyibah, 1999.

Littlejohn, Stephen W., and Karen A. Foss. Encyclopedia of Communication Theory. Vol. 1. London: SAGE Publications, 2009.

MacCluer, Jean Walter. "The Sociobiology Debate." Contemporary Psichology: A Journal of Reviews 25, no. 5 (1980).

Mahmudah, Siti. 'Interaksi Pendidikan Islam Dalam Al Qur'an (Kisah Nabi Ibrahim Dan Nabi Ismail)." Universitas Muhammadiyah Surakarta, 2010.

Maslow, Abraham H. Motivation and Personality. New York: Harper \& Row, 1954.

Milani, Milad. Sufi Politics in the Contemporary West: The Role and Definition of Sufism in the Works of Javad Nurbakhsh (1926-2008), 2017. https://research direct.westernsydney.edu.au/islandora/object/uws\%3A44552/. 
Mizani, Zeni Murtafiati. "Komunikasi Orang Tua Dan Anak Dalam Islam (Tinjauan Pedagogis Komunikasi Nabi Ibrahim Dengan Nabi Isma'il Dalam Al-Qur'an).” Ibriez: Jurnal Kependidikan Dasar Islam Berbasis Sains 2, no. 1 (June 20, 2017): 95-106. https://doi.org/10.21154/ibriez.v2i1.28.

Moosa, Ebrahim. Ghazali Dan Seni Imajinasi Sufistik. Translated by Abdul Kadir Riyadi and Ahmad Kahfi. Surabaya: IMTIYAZ, n.d.

Muniroh, Alimul. "Implementasi Nilai-Nilai Pendidikan Islam Dalam Surah As-Saffat Ayat 102." Darajat: Jurnal Pendidikan Agama Islam 1, no. 1 (March 3, 2018): $1-15$.

Nolen-Hoeksema, Susan, Barbara L. Fredrickson, Geoff R. Loftus, and Willem A. Wagenaar. Atkinson \& Hilgard's Introduction to Psychology. Kanada: Nelson Educations Ltd., 2009.

Papalia, Diane E., Sally Wendkos Olds, and Ruth Duskin Feldman. Psikologi Perkembangan. Translated by A.K. Anwar. Jakarta: Kencana, 2008.

Rahmah, Miftahur. "Mendidik Anak Shaleh: Telaah Kisah Nabi Ibrahim A.S. Dan Ismail A.S." Turast : Jurnal Penelitian Dan Pengabdian 7, no. 1 (July 30, 2019): 45-64. https://doi.org/10.15548/turast.v7i1.763.

Rofdli, Muhammad Faiz, and Suyadi Suyadi. "Tafsir Ayat-Ayat Neurosains ('Aq1 Dalam Al-Qur'an Dan Relevansinya Terhadap Pengembangan Berpikir Kritis Dalam Pendidikan Islam)." JURNAL At-Tibyan Jurnal Ilmu Alquran Dan Tafsir 5, no. 1 (June 30, 2020): 137-51. https://doi.org/10.32505/tibyan. v5i1.1399.

Salina Nen, Fauziah Ibrahim, Ezarina Zakaria, Mohd Norahim Mohamed Sani, and Nor Jana Saim. “Tahap Keyakinan Diri Bekas Penagih Dadah Dalam Pengawasan Di Malaysia: Ke Arah Kepulihan Menyeluruh (Self-Esteem Among Former Drug Addicts Under Observation In Malaysia: Towards A Comprehensive Recovery).” Jurnal Psikologi Malaysia 31, no. 1 (2017).

Sherif, Muzafer, and Carolyn W. Sherif. An Outline of Social Psychology. New York: Harper \& Row, 1956.

Shihab, M. Quraish. Tafsir Al-Misbah: Pesan, Kesan, Dan Keserasian Al-Qur'an. Vol. 15. Jakarta: Lentera Hati, 2009.

Slavin, Robert E. Educational Psycology: Theory and Practice. New Jersey: Pearson Education, 2000.

Soyarslan, Sanem. "The Distinction between Reason and Intuitive Knowledge in Spinoza's Ethics.” European Journal of Philosophy 24, no. 1 (March 1, 2016): 27-54. https://doi.org/10.1111/ejop.12052.

Titus, Harold H. Persoalan-Persoalan Filsafat. Jakarta: Bulan Bintang, 1984.

Widjaya, H.A.W. Komunikasi Dan Hubungan Masyarakat. Jakarta: Bina Aksara, 1986.

Zaimudin, Zaimudin. "Karakter Nabi Ibrahim AS Dalam Al-Qur'an.” Al-Fanar: Jurnal Ilmu Al-Qur'an Dan Tafsir 1, no. 1 (August 30, 2018): 35-74. 